\title{
Front Matter: Volume 11846
}

, "Front Matter: Volume 11846," Proc. SPIE 11846, Saratov Fall Meeting 2020: Laser Physics, Photonic Technologies, and Molecular Modeling, 1184601 (4 May 2021); doi: 10.1117/12.2599484

SPIE. Event: Saratov Fall Meeting 2020, 2020, Saratov, Russian Federation 


\title{
PRO G RESS IN BIO MEDICAL OPTIC S AND IMAG ING \\ Vol. 22 No. 57
}

\section{Sa ratov Fall Meeting 2020}

\section{Laser Physics, Photonic Technologies, and Molecular Modeling}

\author{
Vladimir L Derbov \\ Editor
}

\section{September - 2 October 2020 Saratov, Russian Federation}

\begin{abstract}
Sponsored by
Russian Foundation for Ba sic Research (Russian Federation) - Ministry of Science and Higher Educ ation of the Russia n Federation - Sa ratov State University (Russian Federation) - Russian Academy of Sc iences (Russian Federation) • OSA - The Optic al Soc iety • IEEE - Institute of Electric al a nd Elec tronics Eng ineers • Russian Technology Platform "The Medic ine of the Future" (Russian Federation) • Russian Technology Platform "Photonics" (Russian Federation) • European Technology Platform "Photonic s21" • Samara University (Russian Federation) • INJ ECTRME LLC, Saratov (Russian Federation) - ШC SPE Na nostructured Glass Technology, Saratov (Russian Federation) - Becker \& Hickl GmbH (Gemany) • artphotonic s G mbH (Gemany) - Research Center of Biotechnology RAS (Russian Federation) - Technolnfo Ltd. (Russian Federation) - MR Solutions (United Kingdom) • PicoQuant (Gemany) • InterLabService Ltd. (Russian Federation) • BioLine Group (Russian Federation) - Aspect Imaging Ltd. (United States) • J oumal of Innova tive Optical Hea Ith Sciences (Singa pore) • J oumaI PHOTONICSRUSSIA (Russian Federation)
\end{abstract}

Cooperating Organizations

Russia n Soc iety for Photo biology (Russian Federation) - Sa ratov Sc ience Center of the RAS (Russian Federation) - Biophotonic s.World: The World wide Consortium Biophotonic s4Life - EPIC - European Photonic s Ind ustry Consortium

Technic al Cosponsor and Publisher SPIE

Volume 11846 
The papers in this volume were part of the technical conference cited on the cover and title page. Papers were selected and subject to review by the editors and conference program committee. Some conference presentations may not be available for publication. Additional papers and presentation recordings may be available online in the SPIE Digital Library at SPIEDigitalLibrary.org.

The papers reflect the work and thoughts of the authors and are published herein as submitted. The publisher is not responsible for the validity of the information or for any outcomes resulting from reliance thereon.

Please use the following format to cite material from these proceedings:

Author(s), "Title of Paper," in Saratov Fall Meeting 2020: Laser Physics, Photonic Technologies, and Molecular Modeling, edited by Vladimir L. Derbov, Proc. of SPIE 11846, Seven-digit Article CID Number (DD/MM/YYYY); (DOI URL).

ISSN: 1605-7422

ISSN: 2410-9045 (electronic)

ISBN: 9781510645301

ISBN: 9781510645318 (electronic)

Published by

SPIE

P.O. Box 10, Bellingham, Washington 98227-0010 USA

Telephone +1 3606763290 (Pacific Time)

SPIE.org

Copyright (C) 2021 Society of Photo-Optical Instrumentation Engineers (SPIE).

Copying of material in this book for internal or personal use, or for the internal or personal use of specific clients, beyond the fair use provisions granted by the U.S. Copyright Law is authorized by SPIE subject to payment of fees. To obtain permission to use and share articles in this volume, visit Copyright Clearance Center at copyright.com. Other copying for republication, resale, advertising or promotion, or any form of systematic or multiple reproduction of any material in this book is prohibited except with permission in writing from the publisher.

Printed in the United States of America by Curran Associates, Inc., under license from SPIE.

Publication of record for individual papers is online in the SPIE Digital Library.

\section{SPIE. DIGITAL}

Paper Numbering: A unique citation identifier (CID) number is assigned to each article in the Proceedings of SPIE at the time of publication. Utilization of CIDs allows articles to be fully citable as soon as they are published online, and connects the same identifier to all online and print versions of the publication. SPIE uses a seven-digit CID article numbering system structured as follows:

- The first five digits correspond to the SPIE volume number.

- The last two digits indicate publication order within the volume using a Base 36 numbering system employing both numerals and letters. These two-number sets start with 00, 01, 02, 03, 04, 05, 06, 07, 08, 09, OA, OB ... 0Z, followed by 10-1Z, 20-2Z, etc. The CID Number appears on each page of the manuscript. 


\section{Contents}

LASER SYSTEMS AND APPUCATIONS

1184602 Simulation of the dynamics of a two-frequency VCSEl laser with an extemal cavity [11846-8]

$1184603 \quad$ Numerical investigation of all-fiber erbium-doped bidirectional ring laser for high-prec ision sensing [11846-9]

1184604 Laser monitor application for study of aluminum nanopowder ignition and combustion [11846-11]

1184605 A flexible CPW-FD antenna for ISM and cellular bands fabricated by laser ablation [11846-47]

1184606 Optical rectification of phase modulated signal based on injection-locking single-mode semic onductor laser [11846-10]

1184607 On the optimal operational mode of a CNC-controlled laser machine for ablation of thin metal layers on fiexible dielectric substrates [11846-48]

1184608 Suppression of modulation instability in broad-area semic onductor lasers by injection of extemal optical radiation [11846-23]

1184609 Control of rogue waves in laser with opto-electronic feedback [11846-32]

11846 OA Study of the ablation regimes of thin copper films on dielectric substrates by nanoseconds laser pulses [11846-42]

PHOTONICSOF NANOSTRUCTURES, METAMATERIALS, PHOTONIC BAND-GAP STRUCTURES, LOW-DIMENSIONALSTRUCTURES

11846 OB Reconfigurable broadband terahertz perfect absorbers and generators based on multilayer graphene ribbon plasmonic structures [11846-3]

11846 OC Non-linear optical properties of nanostructured titanium nitride under high-power laser pumping in the fundamental absomtion band [11846-16]

11846 OD Photo-conductance of $\mathrm{MoSi}_{2}$ nanoparticle layers in the near ultraviolet and visible spectral ranges [11846-17]

11846 OE Volumetric anisotropic mic rolattices in compound materials [11846-12] 
$11846 \mathrm{OF}$ Photo-conductance of thin mic rostructured $\mathrm{WO}_{3}$ films in the vic inity of the edge of fundamental absomtion band [11846-13]

11846 OG Photoconductive THtz emitters with high-aspect ratio plasmonic gratings [11846-25]

$11846 \mathrm{OH} \quad$ Gain saturation effect in the cavity with hyperbolic graphene medium [11846-34]

11846 ol Excitation of polanitons near resonance by a nanocomposite plate [11846-44]

11846 0] Casimir-Lifshitz force and plasmons in a structure with two graphene sheets [11846-27]

11846 OK Speed and time of electromagnetic energy transfer in cases of band gap and resonant tunneling [11846-30]

$11846 \mathrm{OL} \quad$ Impact of rare-earth doping upon micro-periodical anisotropy [11846-15]

11846 OM On the technological approach to microfabrication of a meander-line slow-wave structure for millimeter-band traveling-wave tubes with multiple sheet electron beams [11846-38]

\section{LASER BEAM AND PULSE PROPAGATION, DIFRACTION AND COHERENCE}

11846 ON Airy beams for laser manipulation of airbome light-absorbing particles [11846-6]

1184600 Modeling diffraction of a polarized light by three-dimensional nonlinear spiral phase in the near zone [11846-7]

11846 OP Numerical simulation in optical coherence tomography as a tool for development of emerging OCT-modalities [11846-36]

$118460 Q \quad$ Reflection matrices for plane waves composing a beam [11846-41]

11846 OR Evaluation of dynamic visc osity of turbid fluids using optical coherence tomography [11846-31]

11846 OS Change in the polarization of laser radiation upon reflection from an anisotropic plate [11846-40]

11846 0T A single-mode model of cross-sectional method in a smoothly imegulartransition between planarthin-film dielectric waveguides [11846-39]

11846 OU El Ectromagnetically induced transparency of powerful probe pulses [11846-201]

11846 OV Simulation of radiative transfer in dispersive multiphase systems with superc ritical fluidic components [11846-14] 
11846 OW Entanglement in Tavis-Cummings model with Kerrnonlineanity induced by a themal noise [11846-19]

$118460 \mathrm{X}$ Entanglement between two qubits with two-photon transitions interacting with a slightly detuned themal field [11846-20]

\section{SPEC TROSCOPY AND MOLECULAR MODEUNG}

11846 oY Metastable and scattering states of a diatomic beryllium molecule [11846-2]

$11846 \mathrm{OZ}$ The influence of the structure of phosphine oxides on complexation with f-element ions [11846-5]

1184610 Detemination of conformation composition of phenylalanine in gas phase [11846-26]

1184611 Study of resilience of neural network solution of inverse problem based on integration of optical spectroscopic methods to noise in data [11846-43]

1184612 Study of the complexation reactions between dic hloro-substituted 1,10-phenanthroline-2,9dicarboxamide and lanthanide nitrates [11846-35]

1184613 Carbon dots effect on hydrogen bonds in aqueous suspensions [11846-45]

1184614 Machine leaming methods solving an inverse problem in spectroscopy: comparison of efficiency and noise resilience [11846-46]

1184615 Luminescent properties of europium and terbium complexes in mixed solvents [11846-33]

1184616 Structure, vibrational and electronic spectra of silic on doped graphene [11846-28]

1184617 Molecular mechanisms of metal nanopartic les formation by bactenial synthesis [11846-29] 
Proc. of SPIE Vol. 11846 1184601-6

Downloaded From: https://www.spiedigitallibrary.org/conference-proceedings-of-spie on 26 Apr 2023
Terms of Use: https://www.spiedigitallibrary.org/terms-of-use 


\title{
Conference Organizers
}

\author{
Saratov State University (Russian Federation) \\ Research-Educational Institute of Optics and Biophotonics of Saratov State \\ University (Russian Federation) \\ International Research-Educational Center of Optics and Biophotonics of Saratov \\ State University (Russian Federation) \\ Institute of Biochemistry \& Physiology of Plants \& Microorganisms of the RAS \\ (Russian Federation) \\ Institute of Precision Mechanics and Control of the RAS (Russian Federation) \\ Saratov State Medical University named after V.I. Razumovsky \\ (Russian Federation) \\ Volga Region Center of New Information Technologies of Saratov State University \\ (Russian Federation) \\ Tomsk State University (Russian Federation) \\ ITMO University (Russian Federation) \\ Bauman Moscow State Technical University (Russian Federation) \\ Institute of Solid-State Physics of the RAS (Russian Federation) \\ Prokhorov Institute of General Physics of the RAS (Russian Federation) \\ Bach Institute of Biochemistry, Research Center of Biotechnology of the RAS \\ (Russian Federation) \\ Sechenov First Moscow State Medical University (Russian Federation) \\ Institute of Ultra-High Frequency Semiconductor Electronics of the RAS \\ (Russian Federation) \\ Biomedical Photonics Committee of Chinese Optical Society (China) \\ SPIE Student Chapters of: \\ Saratov State University (Russian Federation), \\ Bauman Moscow State Technical University (Russian Federation), \\ Institute of Solid-State Physics of the RAS (Russian Federation), and \\ Samara University (Russian Federation) \\ OSA Student Chapters of: \\ Saratov State University (Russian Federation) and \\ Bauman Moscow State Technical University (Russian Federation)
}


Proc. of SPIE Vol. 11846 1184601-8 Downloaded From: https://www.spiedigitallibrary.org/conference-proceedings-of-spie on 26 Apr 2023
Terms of Use: https://www.spiedigitallibrary.org/terms-of-use 